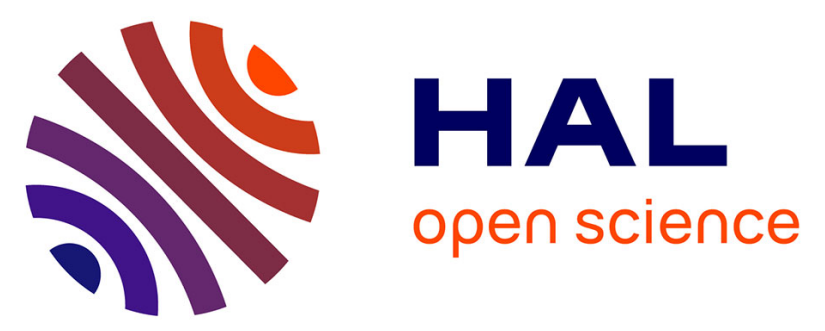

\title{
Revisiting and improving the preparation of silicon-based electrodes for lithium-ion batteries: ball milling impact on poly(acrylic acid) polymer binders
}

Thibaut Chartrel, Mariama Ndour, Véronique Bonnet, Sébastien Cavalaglio, Luc Aymard, Franck Dolhem, Laure Monconduit, Jean-Pierre Bonnet

\section{To cite this version:}

Thibaut Chartrel, Mariama Ndour, Véronique Bonnet, Sébastien Cavalaglio, Luc Aymard, et al.. Revisiting and improving the preparation of silicon-based electrodes for lithium-ion batteries: ball milling impact on poly(acrylic acid) polymer binders. Materials Chemistry Frontiers, 2019, 3, pp.881891. 10.1039/c8qm00660a . hal-02090028

\section{HAL Id: hal-02090028 \\ https://hal.science/hal-02090028}

Submitted on 4 Jan 2021

HAL is a multi-disciplinary open access archive for the deposit and dissemination of scientific research documents, whether they are published or not. The documents may come from teaching and research institutions in France or abroad, or from public or private research centers.
L'archive ouverte pluridisciplinaire HAL, est destinée au dépôt et à la diffusion de documents scientifiques de niveau recherche, publiés ou non, émanant des établissements d'enseignement et de recherche français ou étrangers, des laboratoires publics ou privés. 


\section{Revisiting and improving the preparation of silicon-based electrodes for lithium-ion batteries: ball milling impact on poly(acrylic acid) polymer binders $\dagger$}

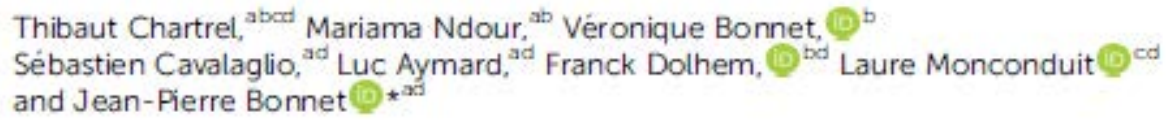

This study revisits and optimizes silicon/carbon/polylacrylic acid) - (PAA) composite anode preparation for lithium-ion batteries. The objective is to analyze the specific impact of the high energy ball milling step on the PAA polymer binder and on the composite anode electrochemical behavior in order to improve cycling performance. For this purpose, three commercial PAAs with 15,450 and $3000 \mathrm{~kg} \mathrm{~mol}^{-1}$ average molar masses are considered. PAA structural alterations induced by ball milling are investigated by SEC, IRTF, ${ }^{1} \mathrm{H}$ NMR and TGA. It appears that PAA $15 \mathrm{k}$ is slightly degraded while higher molar mass PAAs are significantly deteriorated. An innovative optimized formulation, combining (1) ball milling of carbon and Si only followed by [2] magnetic stiming of this mixture with PAA and a dispersant is proposed and compared to an all ball milling formulation. The first step is essential to get good electrochemical performance and the second enables the maintenance of polymer integrity. The highest electrochemical capacity retention after 20 cycles is obtained for the PAA $450 \mathrm{k}$-based electrode (84\%) compared with those of PAA $15 \mathrm{k}$ and PAA $3000 \mathrm{k}$ of $62 \%$ and $29 \%$ respectively. Interestingly, this capacity retention is also significantly improved compared with that of the corresponding PAA $450 \mathrm{~K}$ all ball milling formulation electrode $(65 \%$. 


\section{Introduction}

Development of new electrochemical technologies for nomadic power storage as well as the optimization of the existing ones is currently a crucial issue. Lithium-ion batteries (LiBs) constitute a largely widespread and advanced power source technology for the actual electrochemical cell market. ${ }^{1-3}$ Carbon graphite, the most common negative electrode material (intercalation-type),

4 Leharatoire de Réartivité et Chimie des Salides (CNRS UMF' 73I 4), Lnivor sité de Picardie fules Vone, 3.3 Fue Saint Lai, 80039 Amions Ceder, France E-mali: jean piore. bonnetigu picardic.f

"Labarataire de Ghycachimie, des Antimicrabiens et des Agroressources, (CNFS UMR 7378), toriversitz de Ficardie fules Verne, 33 fae Saint Ial, soa39 Amiens Cieda, France

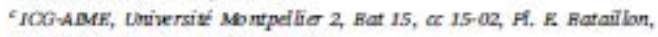
34095 Manpellier cedex S, France

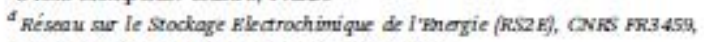
33 Fue Saint L.ar, sou39 Amions Ceder, France

† Electronic supplementary information (ESI) available: IKTF spectra (ATK) of pristine and of $30 \mathrm{mnSPEX}$ ball milled PAA $15 \mathrm{k}$, PAA $450 \mathrm{k}$ and PAA $3000 \mathrm{k}$ (Fig. S1) and porosity $(\%)$ and active mass loeding $\left(\mathrm{mg} \mathrm{cm}^{-2}\right)$ of PAA $15 \mathrm{k}$, PAA $450 \mathrm{k}$ and PAA $3000 k$ based dectrodes using formulation 1 (a), formulation 2 (b) and formulation 3 (c) (rable s1). See DOL: 10.1039/c8qm00660a is characterized by its great electrochemical stability, and a

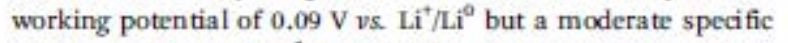
capacity of $372 \mathrm{~mA} \mathrm{~h} \mathrm{~g}^{-1}$. Some other active materials, especially alloy type materials such as silicon (Si) or tin (Sn) but also conversion-type materials like metal oxides or hydrides, are under thorough investigation and may be used as substitutes in the near future. ${ }^{4-7} \mathrm{Si}$ is especially promising because of its high availability, working potential of about $0.40 \mathrm{~V}$ vs. $\mathrm{Li}^{+} / \mathrm{Li}^{\circ}$ and impressive specific capacity of $3579 \mathrm{~mA} \mathrm{~h} \mathrm{~g}^{-1.8}$. This high capacity is related to the $\mathrm{Li}_{1} \mathrm{Si}_{4}$ phase obtained during the lithiation process (reaction of $375 \mathrm{Li}$ per Si atom) ${ }^{2}$ while graphite gives $\mathrm{LiC}_{6}$ (insertion of only $1 \mathrm{Li}$ for $6 \mathrm{C}$ atoms). This difference is also associated with a huge volume expansion observed in $\mathrm{Si}$ (about $280 \%{ }^{10}$ ) to be compared with about $10 \%$ only for graphite. ${ }^{11}$ This Si expansion is unfortunately responsible for detrimental effects: particle pulverization, electrode particle disconnections and loss of electrical contact resulting in premature capacity fading. ${ }^{12-14}$ Another Si expansion side effect is continuous cracks into the solid electrolyte interphase (SEI), resulting in continuous SEI formation and also fast capacity decay. ${ }^{15-17}$ As a consequence, studies aim at increasing the Si electrochemical reversibility via several ways including, on one side, alloying 
Si alloys or playing with particle shape (use of Si-based alloys, ${ }^{18-22} \mathrm{~S}$ nanoparticles, ${ }^{25-x}$ nanotubes, ${ }^{27}$ nanowires ${ }^{20}$ and thin layers ${ }^{29}$ ) and, on the other side, the use of several kinds of polymer binders. ${ }^{x, 31}$ Moreover, because Si electronic conductivity is not sufficient, electrodes are formulated with conducting carbon for electron transport. Several carbons were thus studied, ${ }^{32}$ like "Ketjenblack" or "super P" carbons. The Si negative electrode is consequently a compromise composite structure made of $\mathrm{Si}$, conducting carton and a polymer binder. Regarding binders, poly(vinylidene fluoride) (PVDF), one of the first investigated LiB anode polymer binders, is not convenient because it only interacts with $\mathrm{Si}$ by weak van der Waals forces. This kind of interaction is not strong enough to maintain electrode cohesion and prevent particle disconnections. ${ }^{33-35}$ It seems that stronger interactions between Si particles and polymers, like hydrogen bonding or maybe covalent bonding are actually required. Poly(electrolytes) bearing carboxylic acid functions $\left(\mathrm{COOH} / \mathrm{COO}^{-}\right)$like carboxymethyl cellulose (CMC) and poly(acrylic acid) (PAA) were consequently investigated especially for Sibased anodes, allowing substantial electrode performance enhancement compared to that of PVDF. These conclusions are drawn by many groups such as Koo et al. who highlighted capacity retention values of about $1300 \mathrm{~mA} \mathrm{~h} \mathrm{~g}^{-1}$, $900 \mathrm{~mA} \mathrm{~h} \mathrm{~g}^{-1}$ and $100 \mathrm{~mA} \mathrm{~h} \mathrm{~g}^{-1}$ for, respectively, CMC, PAA and PVDF binder-based silicon electrodes after 100 cycles. ${ }^{\$ 6}$ Moreover, polymer binder molecular average mass also constitutes an important parameter which was already studied by several groups..$^{37-40}$ Briefly, it seems that CMC's molecular weight influences electrochemical performances, with an optimum value, estimated at $700 \mathrm{~kg} \mathrm{~mol}^{-1}$ by Bridel et al. . $^{30}$ Besides, it is important to note that in several laboratory-scale studies from the literature the usual Sipolymer/carbon shurry formulation contains a highenergy ball milling step in the process, using a "Fritsch Pulverisette" or "SFEX" apparatus. ${ }^{41-45}$ In complement, in other publications the description of the slurry formulation process remains undear ${ }^{*-53}$ with no precision about polymer ball milling or not. Finally, while the effect of milling was already investigated for $\mathrm{Si}$ alone, ${ }^{\mathrm{s}}$ there is no specific study reported for the polymer binder.

The purpose of this study is to determine the effect of high energy ball milling on poly(acrylic acid) (PAA) and, from there the Si composite electrode's electrochemical properties. The effect of high energy ball milling on the Si particle size was also investigated in complement. It must have indeed a beneficial effect on electrochemical capacity retention. ${ }^{54}$ it is here worth noting that many electrode formulation studies from the literature were realized from milled polymer binders without considering eventual binder degradation. For the first time, herein, we take into account the polymer structure evolution impact during the formulation process and thus the molecular mass changes.

\section{Experimental section}

\subsection{Materials}

Poly(acrylic acid) sodium salt (PAA-Na) (average molecular weight $=15000)($ PAA 15k) was provided by Sigma Aldrich (USA) and then protonated with an acidic ion exchange resin.
Protonation was conf irmed by ${ }^{1} \mathrm{H}$ NMR and $\mathrm{pH}$ value measurement (not shown here). Poly(acrylic acid) (PAA) (average molecular weight $=450000)(\mathrm{PAA} 450 \mathrm{k})$ and (average molecular weight $=$ 3000000 ) (PAA $3000 \mathrm{k}$ ) were provided by Sigma Aldrich (USA) and used as received. Silicon powder (Si) was provided by Umicore. It consists of spherical particles with median estimated at about $304 \mathrm{~nm}$. Silicon has an initial $\mathrm{SiO}_{2}$ content evaluated at $5 \%$. Conducting additive Super 065 carbon (Cc65) was purchased from Timcal, Triton X-100 ( $\mathrm{Tx}_{100}$ ) was purchased from Sigma Aldrich and used as received. Fluoro ethylene carbonate (FEC) was provided by Sigma Aldrich and used as received. LP30 commercial electrolyte (1 M LiPF 6 in 1:1 w: w ethylene carbonatedimethyl carbonate, $\mathrm{EC} / \mathrm{DMC}$ ) was purchased from Merck and used as received.

\subsection{Characterization techniques}

Size exclusion chromatography (SEC) was performed with IB. 6 6B, LB803 and LB-805 columns (Shodex, Germany) using a MAIS detector (DAWN $8^{+}$HELEOS II, Wyatt Technology), an RI detector (RID-10A, Shimadzu) and a UV-VIS detector (SPD-20A, Shimadzu). The eluent was a NaNO$/ \mathrm{NaN}_{3}$ solution $\left(18 \mathrm{~g}\right.$ of $\mathrm{NaNO}_{3}$ and $0.6 \mathrm{~g}$ of $\mathrm{NaN}_{\mathrm{s}}$ in $1 \mathrm{~L}$ of water). Electrode porosity measurements were calculated from a theoretical calculation taking into account the electrode thickness and the different material percentages by weight. Pycnometric densities were performed on an AccuPye 1330 gas pycnometer using helium gas. Runs were performed 5 times using a $3.5 \mathrm{~cm}^{3}$ cell. Fourier transformed inf rared (FTIR) analyses were done with attenuated total reflection (ATR) mode on a Shimadzu IRAffinity-1S with $4 \mathrm{~cm}^{-1}$ resolution, from 400 to $4000 \mathrm{~cm}^{-1}$. Thermo-gravimetric analyses (TGA) were performed under argon flow ( $50 \mathrm{~mL} \mathrm{~min}{ }^{-1}$ ) at a $5^{\circ} \mathrm{C} \mathrm{min}{ }^{-1}$ temperature ramp on a STM $49 \mathrm{C}$ Netzsch apparatus coupled to a quadrupolemass spectrometer (QMS 403 Aeolos). Proton-nuclear magnetic resonance ( ${ }^{1} \mathrm{H}$ NMR) spectra were recorded at $298 \mathrm{~K}$ on a Bruker $400 \mathrm{MHz}$ Avance III HD. PAA samples were placed in $\mathrm{D}_{2} \mathrm{O}$ solution in $5 \mathrm{~mm}$ NMR tubes. Silicon particle size distributions before (pristine) and after ball milling were estimated with a laser diffraction particle analyzer Mastersizer 3000 (Malvern Instruments, Malvern, U.K) equipped with a Hydro BV (Mahern Instruments, Malvem, U.K) dispersion system. This technique permits the determination of particle sizes from $10^{-3}$ to $3 \times 10^{3} \mu \mathrm{m}$. The partickes were dispersed in a mixture of water and Triton X-100 as dispersing agent ( $500 \mu \mathrm{L}$ of $1 \mathrm{wt} \%$ of TX-100 in $500 \mathrm{~mL}$ of distillated water). The particles were dispersed with an ultrasonic time ratio of $0.1 \mathrm{~s}$ pulsel $0.1 \mathrm{~s}$ rest and with an energy of $96 \mathrm{~W}$ and during $90 \mathrm{mn}$ prior to measurement. The Mastersizer 3000 analyzer uses two light soures (red and blue with respective wavelengths of $633 \mathrm{~nm}$ and $470 \mathrm{~nm}$ ) and scattered light intensity argular variation after passing through the wet sample is measured. The obscuration range is $3.02 \%$ for $\mathrm{Si}$ pristine and $12.69 \%$ for ball milled Si.

\subsection{Electrochemical studies and electrode preparations}

Electrodes were prepared with Si/Cc65/PAA weight $\%$ formulation: $70 / 15 / 15$. In all cases, the total $\mathrm{Si} / \mathrm{Cc} 65 / \mathrm{PAA}$ total mass was fixed at $600 \mathrm{mg}$. The three formulations are:

(1) Formulation 1 - usual ball milling formulation: Si, Cc65 and PAA were placed with an adapted quantity of deionized 
water in a stainless steel ball mill jar (volume $=50 \mathrm{~mL}$ ) with 3 stainless steel balls (10 $\mathrm{mm}$ of diameter) and subsequently ball milled in a highenergy (SPEX ball mill) milling for 30 minutes at a frequency of $50 \mathrm{~Hz}$. The resulting shrry was then coated on a $15 \mu \mathrm{m}$ thick structured copper foil. The films were dried at room temperature ovemight. Electrode porrsity is estimated to be around $60 \%$ for $450 \mathrm{k}$ and $3000 \mathrm{k}$ PAAs and around $65 \%$ for $15 \mathrm{k}$ PAA

(2) Formulation 2 - ball milling-free formulation: Si, Oe65, PAA and $\mathrm{TX}_{100}(7 \mathrm{mg})$ were placed in a pill and magnetically stirred with an adapted quantity of deionized water for 120 minutes. The resulting slurry was then coated on a $15 \mu \mathrm{m}$ thick structured copper foil. The films were dried at room temperature overnight. The electrode porosity was estimated to be around $70 \%$.

(3) Formulation 3 - optimized formulation: Si and Cc65 were placed in a stainless steel ball mill jar (volume $=50 \mathrm{~mL}$ ) with 3 stainless steel balls ( $10 \mathrm{~mm}$ of diameter). The jar was shaken in a high-energy SPEX ball mill for 30 minutes at a frequency of $50 \mathrm{~Hz}$. PAA, Triton X-100/TX-100 (7 mg) and an adapted quantity of deionized water were then added to the obtained composite powder and magnetically stirred in a pill for 120 minutes. The resulting slurry was then coated on a $15 \mu \mathrm{m}$ thick structured copper foil. The films were dried at room temperature overnight. Electrode porosity is estimated to be around $70 \%$ for both $15 \mathrm{k}$ and $450 \mathrm{k}$ PAAs and around $60 \%$ for $3000 \mathrm{k}$ PAA. In all cases, $1 \mathrm{~cm}^{2}$ disk electrodes were cut and put in an argon-filled glovebox to be assembled into a 2035 coin cell. One glass fiber disk (Whatman GF/D) was placed between the positive (Si/Cc65/PAA electrode) and negative ( $\mathrm{Li}$ foil) electrodes. The used electrolyte was commercial LP30 (1 M LiPF 6 in $1: 1 \mathrm{w}: \mathrm{w}$ ethylene carbonate) dimethyl carbonate, EQDMC) with 10 wt $\%$ added FEC. Cycling was performed with a Mac-Pile (Claix, France) in galvanostatic mode. The cells were cycled between 0.0 and $2.5 \mathrm{~V}$ vs. $\mathrm{Li}^{+} / \mathrm{Li}^{\circ}$ $\left(20^{\circ} \mathrm{C}\right)$ with $\mathrm{C} / 10(1 \mathrm{Li}$ in $10 \mathrm{~h})$ cycling rate.

\section{Results and discussion}

\subsection{Investigation of polymer binder and silicon partide ball milling impact}

SEC-MAIS results of pristine and $30 \mathrm{mn}$ ball milled PAA samples are presented in Fig. 1 and the corresponding average molar masses $\bar{M}_{\mathrm{n}}$ and $\bar{M}_{\mathrm{w}}$ and polydispersity index $I_{\mathrm{p}}$ are summarized in Table 1. The highest molar mass commercial PAA, indicated as a $3000 \mathrm{~kg} \mathrm{~mol} \mathrm{~m}^{-1}$ PAA could not be analyzed because of solubility issues (incomplete solubilization). Pristine $15 \mathrm{~kg} \mathrm{~mol}^{-1}$ PAA presents molar masses in the range of the commercial product statement $\bar{M}_{\mathrm{n}}=13 \mathrm{~kg} \mathrm{~mol}^{-1}$ and $\bar{M}_{\mathrm{w}}=27 \mathrm{~kg} \mathrm{~mol} \mathrm{~m}^{-1}$ measured, giving a polydispersity of $I_{\mathrm{p}}=2,03$. The pristine $450 \mathrm{~kg} \mathrm{~mol}^{-1}$ PAA molar mass is also close to the expected one but with a higher polydispersity value of $I_{\mathrm{p}}=2.59\left(\bar{M}_{\mathrm{n}}=191 \mathrm{~kg} \mathrm{~mol}^{-1}\right.$ and $\left.\bar{M}_{\mathrm{w}}=495 \mathrm{~kg} \mathrm{~mol}^{-1}\right)$. We then investigated the impact of SPEX ball milling on the PAA samples. The three PAA samples were ball milled under the same conditions used during the formulation process with ball milling for 30 minutes in deionized water. The samples were then lyophilized to obtain a dry powder and analyzed by ${ }^{1} \mathrm{H}$ NMR, FTIR, TGA and SEC-MALS. From Fig. 1 and Table 1 it can be noted that $450 \mathrm{~kg} \mathrm{~mol}^{-1}$ PAA undergoes a huge average molar mass decrease, from $\bar{M}_{\mathrm{n}}=191$ to $65 \mathrm{~kg} \mathrm{~mol}^{-1}$ and $\bar{M}_{\mathrm{w}}=495$ to $115 \mathrm{~kg} \mathrm{~mol}^{-1}$ after the ball milling step while the $15 \mathrm{~kg} \mathrm{~mol}^{-1}$ PAA molar mass is not significantly impacted by ball milling with a very small variation from $\bar{M}_{\mathrm{n}}=13$ to $10 \mathrm{~kg} \mathrm{~mol}^{-1}$ and $\bar{M}_{\mathrm{w}}=27$ to $23 \mathrm{~kg} \mathrm{~mol}^{-1}$. It is interesting to note here that for the $450 \mathrm{~kg} \mathrm{~mol}^{-1}$ PAA sample the polydispersity decreases from $I_{p}=2.59$ to 1.77 , meaning that a more homogeneous size distribution is obtained. On the contrary, for $15 \mathrm{k}$ PAA, the polydispersity increases from $I_{\mathrm{p}}=2.08$ to 2.30 with ball milling. These apparently contradictory results are in fact in acordance with the work of Smith et al. on high-energy mechanical milling of PMMA. ${ }^{5 s}$ These authors demonstrated that, firstly, the ball milling induces a decrease in the PMMA samples' average molar mass and that it follows a kinetics correlated with the molecular mass (the higher the pristine sample's average molar mass, the faster the degradation kinetics). They also show, secondly a polymer sample polydispersity evolution in two steps with an initial broadening followed by a narrowing with the increase of

Table 1 SEC-MALS analysis of pristine and ball milled $15 \mathrm{k}$ and $450 \mathrm{~K}$ PAAs

\begin{tabular}{|c|c|c|c|c|c|c|}
\hline & \multicolumn{3}{|c|}{ Pristine } & \multicolumn{3}{|c|}{ Ball milled } \\
\hline & $M_{w}$ & $M_{n}$ & $I_{\mathrm{p}}$ & $M_{\mathrm{w}}$ & $M_{\mathrm{n}}$ & $I_{\mathrm{p}}$ \\
\hline PMA $15 \mathrm{~kg} \mathrm{~mol}^{-1}$ & 27 & 13 & 208 & 23 & 10 & 2.30 \\
\hline PMA $450 \mathrm{~kg} \mathrm{~mol}^{-1}$ & 495 & 191 & 259 & 115 & 65 & 1.77 \\
\hline
\end{tabular}

a)

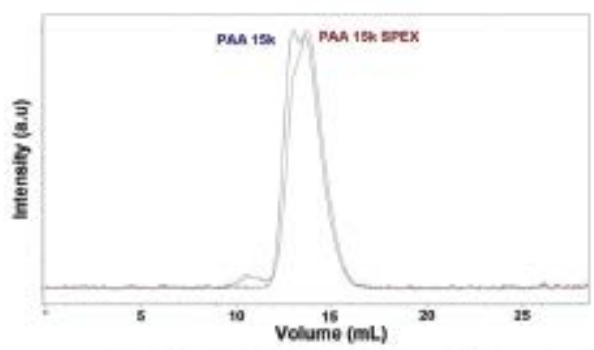

b)

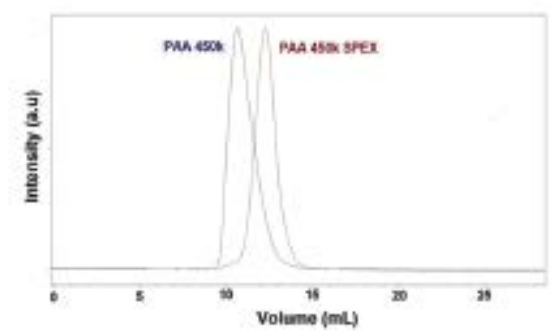

Fig. 1 SEC chromatograms of pristine (blue line) and $30 \mathrm{mn}$ SPEX ball milled (red line) PAA 15k (a) and PAA 450k (b). 
milling time duration. From these results it can be concluded in our case, for the same ball milling conditions, that the $450 \mathrm{~kg} \mathrm{~mol}^{-1}$ PAA sample is highly impacted while the $15 \mathrm{~kg} \mathrm{~mol}^{-1}$ PAA sample is less so.

To evaluate more precisely the chemical stability and degradation process of the 3 PAA binders after SPEX ball milling, FTIR, ${ }^{1} \mathrm{H}$ NMR and thermogravimetric analysis (TGA) of the polymers were also performed before and after the 30 minutes ball milling. The FTIR spectra of the pristine and ball milled samples are similar, meaning no noticeable chemical group structure evolution difference in the polymers. All the peaks at $1704 \mathrm{~cm}^{-1}$ ( $\mathrm{C}=\mathrm{O}$ stretching), $1455 \mathrm{~cm}^{-1}$ ( $\mathrm{CH}_{2}$ deformation), and 1418,1239 and $1169 \mathrm{~cm}^{-1}$ (C-O stretching coupled with $\mathrm{O}-\mathrm{H})^{56}$ are preserved (Fig. S1, ESI + ). ${ }^{1} \mathrm{H}$ NMR spectra of pristine and ball milled PAA samples in $\mathrm{D}_{2} \mathrm{O}$ are shown in Fig. 2 . All the pristine samples present two groups of peals, a pseudo-singlet at around $2.42 \mathrm{ppm}$, attributed to the methine group $(-\mathrm{CH})$ linked to a $\mathrm{COOH}$ function and a pseudo-triplet around 1.63, 1.76 and $1.93 \mathrm{ppm}$ attributed to the methylene group $\left.\left(-\mathrm{CH}_{2}\right)\right)^{57,58}$ These signals cannot actually be qualified as singlet and triplet because of the non-equivalency of the protons. The carbon of methine groups $-\mathrm{CH}$ corresponds in fact to a pseudochiral center $-\mathrm{C} H$ and the steric arrangement of these pseudoasymmetric centers along the polymer chain is called tacticity and is very wellknown for vinylic polymers. ${ }^{50}$ In our PAA sample, for the methylene region, the low-field and high-field bands at $1.93 \mathrm{ppm}$ and $1.63 \mathrm{ppm}$, respectively, are attributed to nonequivalent protons in " $\mathrm{m}$ " diads and the middle band at $1.76 \mathrm{ppm}$ corresponds to the " $\mathrm{r}$ " diad. ${ }^{57}$ The percent of each diad " $\mathrm{m}$ " and " $\mathrm{r}$ " can be simply calculated here from their corresponding relative intensities. It is very similar in each pristine PAA sample, giving a value of " $\mathrm{m}$ " and " $\mathrm{r}$ " close to 0.5 , ie probabilities of " $\mathrm{r}$ " and " $\mathrm{m}$ " configurations of approximately $50 \%$ and $50 \%$ ("m" $" \mathrm{~m} / \mathrm{r}$ " couples of $0.53 / 0.47 ; 0.58 / 0.42 ; 0.52 / 0.48$ for PAA $15 \mathrm{k}$, $450 \mathrm{k}$ and $3000 \mathrm{k}$ were, respectively, measured). This result establishes that all 3 commercial samples are atactic, without preferential stereochemical sequences for pseudochiral centers $-\mathrm{C}^{*} \mathrm{H}$, i.e. totally random polymer chains according to Bernoulian statistics. This result was also established previously for other commercial PAA samples by Chen Chang et al, but with lower molar mass polymers. ${ }^{\text {sa }}{ }^{1}$ H NMR spectra of ball milled PAA samples are presented in Fig. 2. 15k ball milled PAA NMR shows an unmodified response with respect to the pristine one (Fig. 2a). Concerning 450k and $3000 \mathrm{k}$ PAAs, a significant signal enlargement can be observed at the same time for methine $-\mathrm{CH}$ and methylene $-\mathrm{CH}_{2}$ protons (Fig. $2 \mathrm{~b}$ and c). This growth is due to an increase of the chemical environment diversity caused by some polymer backbone breaks leading to smaller fragments. These observations can be quantified by an inerease of signal wid th at half height values. Taking the methine $-\mathrm{CH}$ group as a reference, the 15k PAA width at half height increases by $0.83 \mathrm{~Hz}$ while those of PAA $450 \mathrm{k}$ and $3000 \mathrm{k}$ PAAs increase, by $179 \mathrm{~Hz}$ and $14 \mathrm{~Hz}$, respectively, after ball milling. These results indicate that the different PAAs are not equally degraded, with a higher degradation ratio for 450k PAA than for 3000k PAA. 15k PAA appears to be less affected. This is coherent with our previous SEC study, showing that the PAA $15 \mathrm{k}$ is less degraded by ball milling compared with PAA $450 \mathrm{k}$. TGA thermograms at a $5{ }^{\circ} \mathrm{C} \mathrm{min}{ }^{-1}$ rate under argon for both pristine and ball milled PAA samples are shown in Fig. 3. PAA samples actually decompose in 3 successive steps, according to the literature. ${ }^{60,51}$ The first weight loss corresponds to absorbed water emission and oecurs until $95^{\circ} \mathrm{C}$. This loss represents between 4 and $9 \%$ of the total mass. The second loss of mass is attributed to a dehydration step. Reported with a starting temperature $\left(T_{\text {omes }}^{\circ} 2\right)$ between $141{ }^{\circ} \mathrm{C}^{60}$ and $170{ }^{\circ} \mathrm{C}^{61}$ and with a maximum at about $250^{\circ} \mathrm{C}$; it corresponds to water loss from carboxylic acids, leading to anhydride group formation. This mass loss corresponds to around $23 \%$ weight. The last step ( $51 \%$ of mass loss), starts from $300{ }^{\circ} \mathrm{C}\left(T_{\text {osec }}^{\circ}{ }^{3}\right)$ and is associated with decarboxylation and polymer chain scissions. ${ }^{61}$ The resulting mass is finally reported to be close to $17 \%$ at $500{ }^{\circ} \mathrm{C}^{60}$ All our pristine and ball milled samples are following this degradation process. More prexisely, in our PAA samples (Fig. 3a-c), all the ball milled ones systematically present lower $T_{\text {onet }}^{\circ} 2$ and $T_{\text {oset }}{ }^{3}$ compared to the pristine samples. For PAA 15k $T_{\text {oset }}^{\circ} 2=164^{\circ} \mathrm{C}$ before and $117^{\circ} \mathrm{C}$ after ball milling, for PAA $450 \mathrm{k} T_{\text {one }}^{\circ} 2=155^{\circ} \mathrm{C}$ before and $148^{\circ} \mathrm{C}$ after and for PAA $3000 \mathrm{k} T_{\text {onet }}^{\circ} 2=145^{\circ} \mathrm{C}$ before and $141^{\circ} \mathrm{C}$ after. For $T_{\text {anser }}^{\circ} 3$ it decreases from $284^{\circ} \mathrm{C}$ to $235^{\circ} \mathrm{C}$ for PAA $15 \mathrm{k}$, from $301{ }^{\circ} \mathrm{C}$ to $296{ }^{\circ} \mathrm{C}$ for PAA $450 \mathrm{k}$ and from $316^{\circ} \mathrm{C}$ to $293{ }^{\circ} \mathrm{C}$ for PAA $3000 \mathrm{k}$. This $T_{\text {oeset }}^{\circ}$ decrease means actually that ball milling leads to some polymer structure alterations and therefore facilitates decomposition. This observation is in accordance

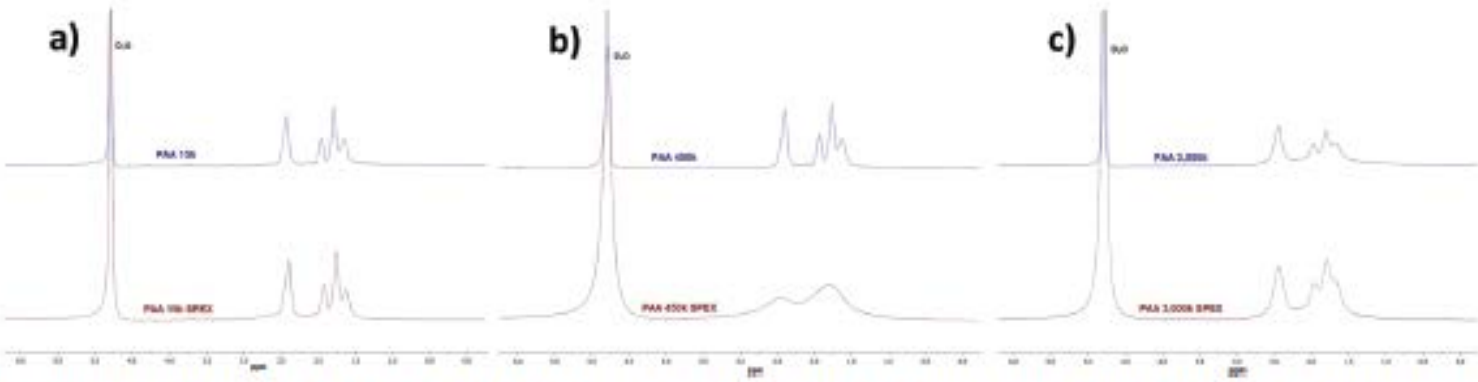

Fig. $2{ }^{1} \mathrm{H}$ NMR spectra of pristine (blue line) and $30 \mathrm{mn}$ SPEX ball milled (red line) PAA 15k (a), PAA 450k (b) and PAA $3000 k$ ic) solutions in D,O. 
a)

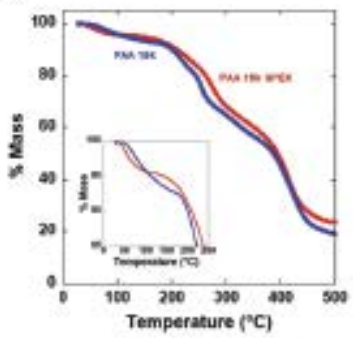

b)

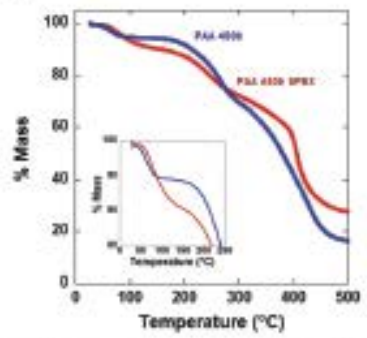

c)

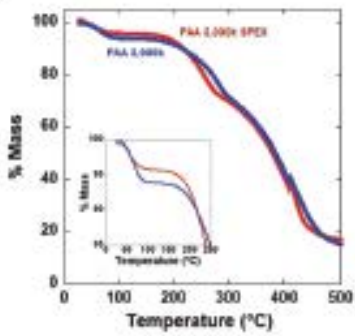

Fig. 3 TGA curves of of pristine (blue line) and $30 \mathrm{mn}$ SPEX ball milled (red line) PAA. 15k (al. PAA 450k (b) and PAA 30D0k (c) (argon, heating rate $5^{\circ} \mathrm{C} \mathrm{min}^{-1}$, insets: close-up until $250 \mathrm{C}$.

with work of Castricum et $a L^{62}$ and also in accordance with our SEC and NMR results. TGA analyses show then that ball milling drastically reduces the properties of $450 \mathrm{k}$ PAA while $15 \mathrm{k}$ and $3000 \mathrm{k}$ PAAs seem to be less damaged by this milling step.

Besides, silicon particle degradation by ball milling is studied by a laser diffraction analyzer and the results are presented in Fig. 4. A multimodal distribution with three Si particle populations around $30 \mathrm{~nm}, 380 \mathrm{~nm}$ and $3.34 \mu \mathrm{m}$ and respective percentages of $47.00 \%, 43.55 \%$ and $9.45 \%$ are found for pristine silicon. After ball milling, these populations are conserved (respectively, $30 \mathrm{~nm}, 340 \mathrm{~nm}$ and $4.31 \mu \mathrm{m}$ ) but the particles' respective percentages are quite modified $(14.44 \%, 23.61 \%$ and $35.50 \%$, respectively). Moreover, a 4 th population at $33.20 \mu \mathrm{m}$, corresponding to $26.45 \%$, appears. This morphology change (global average particle size increase after ball milling) corresponds to a clustering of silicon particles, with agglomerates constituted of sub-micrometric particles welded together. This phenomenon was previously observed by Gauthier et al. ${ }^{54}$ for Si particles of 1 to $5 \mu \mathrm{m}$ after $20 \mathrm{~h}$ of SPEX ball milling. It must be noted that this $\mathrm{Si}$ particle ball milling is beneficial for

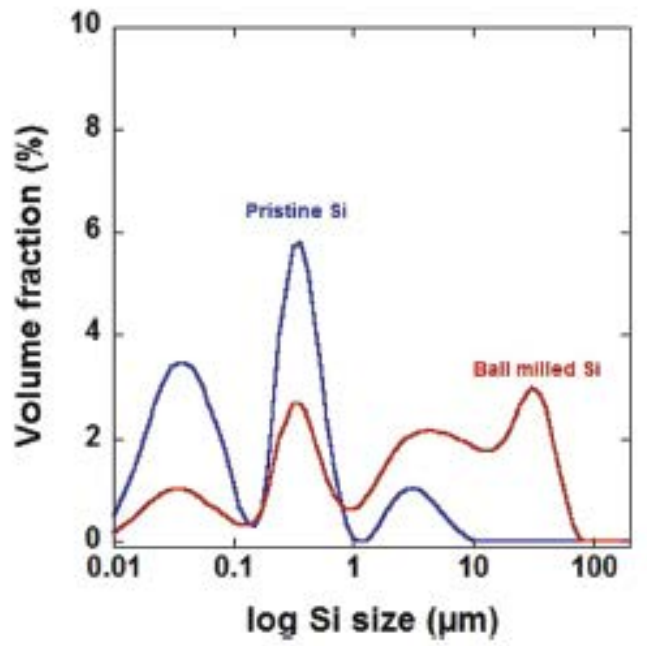

Fig. 4 Particle size distributon anatyses of pristine silicon (Dlue tine) and $30 \mathrm{~m}$ SPEX ball milled silicon (red line) powders electrochemistry with better capacity retention attributed to a nanostructuration phenomenon, creating grain boundaries where faster Li diffusion may happen. ${ }^{54}$

\subsection{Electrochemical characterization}

The three different PAA chain length samples in their acidic form were first used as binders in silicon-based composite electrodes following a formulation including polymer ball milling (formulation 1, see Experimental part). A silicon/ carbon/polymer mixture (Si/Co65/PAA) (70/15/15 wt\%) was electrochernically tested against lithium metal (half cell) using liquid electrolyte LP30 with 10 wt $\%$ added FEC (see Experimental part). The corresponding electrochemical results (potential (V) versus specific capacity curves (mA h g ${ }^{-1}$ of Si)) are shown in Fig. 5. The active mass loadings (in mg $\mathrm{cm}^{-2}$ ) are, respectively, 1.19 for PAA $15 \mathrm{k}$ and $450 \mathrm{k}$ and 1.05 for PAA $3000 \mathrm{k}$ electrodes and the electrode porosities are estimated to be about $60 \%$ for PAA $450 \mathrm{k}$ and $3000 \mathrm{k}$ electrodes ( $65 \%$ for PAA 15k) (Table S1, ESI†). In complement, Table 2 summarizes some electrochemical characteristics (1st charge capacity ( $\mathrm{mA} \mathrm{h} \mathrm{g}{ }^{-1}$ ), 1st cycle coulombic efficiency $(C B)(\%)$, 20th charge capacity ( $\mathrm{mA} \mathrm{h} \mathrm{g} \mathrm{g}^{-1}$ ), 20th charge capacity/1st charge capacity $(\%)$, and polarization 1 st cycle/20th cycle (V)). First, the $450 \mathrm{~kg} \mathrm{~mol}^{-1}$ PAA-based cell presents a better $\mathrm{CE}$ at the first cycle compared to $3000 \mathrm{k}$ and $15 \mathrm{k}$ PAA cells ( $85 \%$ for $450 \mathrm{k}$ PAA versus $79 \%$ and $68 \%$, respectively for $3000 \mathrm{k}$ and $15 \mathrm{k}$ PAA). Better capacity retention at the twentieth cycle is also observed for the $450 \mathrm{~kg} \mathrm{~mol}^{-1}$ PAA-based cell, with a charge capacity of $2126 \mathrm{~mA} \mathrm{~h} \mathrm{~g}^{-1}$, to be compared with 960 and 384 for $3000 \mathrm{k}$ and $15 \mathrm{k}$ PAA cells, respectively (Fig. 5b). Polarization curves, which correspond to the difference between the potential of the $(n+1)$ charge and of the $(n)$ discharge, were also estimated for all cases. Both $15 \mathrm{k}$ and $3000 \mathrm{k}$ PAA galvanostatic curves undergo a polarization increase from $0.34 \mathrm{~V}$ at the first cycle to 1.05 and $0.86 \mathrm{~V}$ at the twentieth cycle while 450k PAA's polarization decreases from 0.34 to $0.30 \mathrm{~V}$ under the same conditions (Fig. 5c). These observations are in accordance with a study of $\mathrm{Hu}$ et al. ${ }^{37}$ on graphite rich silicon/ graphite composite anodes for lithium ion batteries using PAA as a binder. These authors show that silicon/graphite-based electrodes with PAAs with an average molecular mass number $\bar{M}_{\mathrm{n}} \approx 150 \mathrm{~kg} \mathrm{~mol}^{-1}$ present better performances compared to that using smaller PAA, with higher capacities of 343 and 
a)
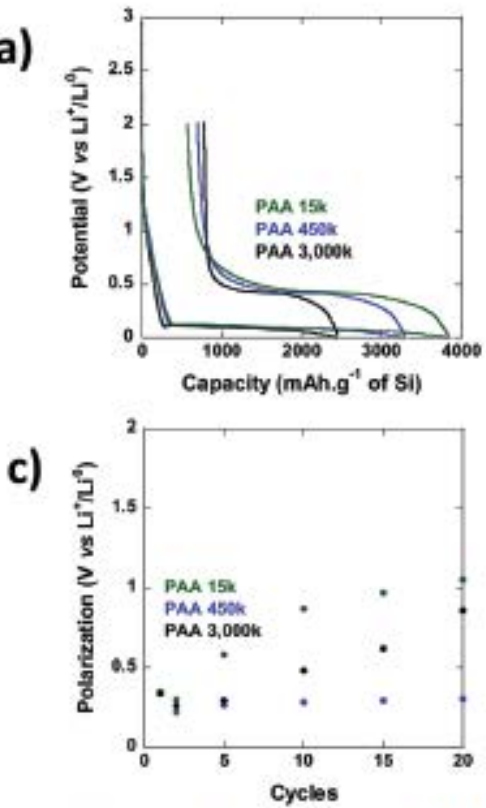
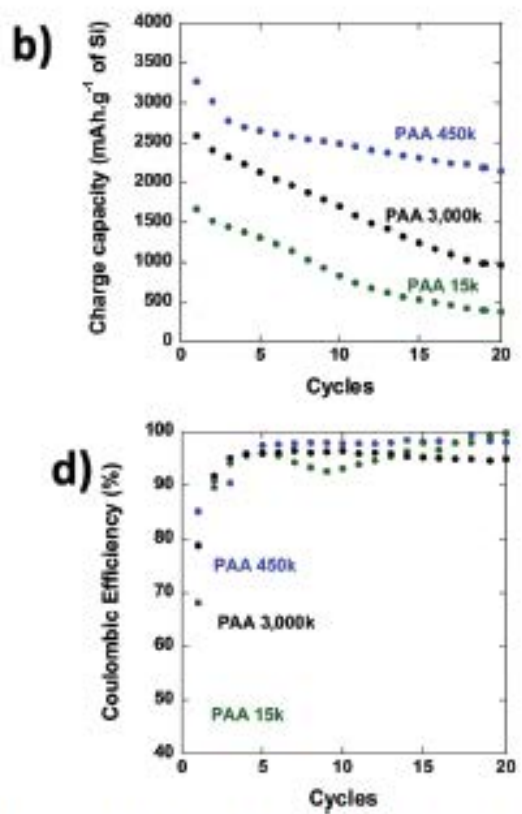

Fig. 5 First galvanostatic cycle profile (a), evolution of charge capacity with cycle curves (bl, polarization evolution curves k) and coulombic efficiency variation (da) of Si/Cc65/Dinder electrodes (70/15/15 wta) with formulation 1 using PAA 15k (green line), PAA 450k (blue line) and PAA 3000k (black line) $\left(20^{\circ} \mathrm{C}, \mathrm{C} / 10 \mathrm{~L} \mathrm{~L}\right.$ in 10 hours) $\mathrm{LP} 30+\mathrm{FEC}(10 \mathrm{v}) \mathrm{L}$, versus $\left.\mathrm{L}^{+} / \mathrm{Li}^{\circ}\right)$

Table 2 Cell characteristcs of $15 k, 450 k$ and $3000 k$ PAA-based electrodes using formulation 1 and the 450k PAA silicon-based electrode using formulation 2

\begin{tabular}{lllll}
\hline Formulation 1 & PM 15k & PM 450k & PM 3000k & Formulation 2 PMA 450k \\
\hline 1st charge $\left(\mathrm{m} \mathrm{h}^{-1}\right)$ & 1669 & 3270 & 2594 & 3456 \\
1st cycle CE $(\%)$ & 68 & 85 & 79 & 76 \\
20th charge $(\mathrm{mA} \mathrm{h} \mathrm{g})$ & 384 & 2126 & 960 & 170 \\
20th charge/1st charge $(\%)$ & 23 & 65 & 37 & 5 \\
Polarization 1st cycle/20th cycle (V) & $0.35 / 1.05$ & $0.34 / 0.30$ & $0.34 / 0.86$ & $0.28 / 1.51$
\end{tabular}

$322 \mathrm{~mA} \mathrm{~h} \mathrm{~g}^{-1}$ after 100 cycles for $\bar{M}_{\mathrm{n}}=147$ and $167 \mathrm{~kg} \mathrm{~mol}^{-1}$ PAAs respectively and of 278 and $224 \mathrm{~mA} \mathrm{~h} \mathrm{~g}^{-1}$ for $\bar{M}_{\mathrm{n}}<$ $24 \mathrm{~kg} \mathrm{~mol}^{-1}$ PAAs. The given explanation is that PAA smaller than $150 \mathrm{~kg} \mathrm{~mol}{ }^{-1}$ may not be able to maintain the ester bonding between the binder and siloxyl groups, leading to some cohesion loss and cracks. It can otherwise be thought, based on the PAA pelota conformation ${ }^{41}$ that a high molar mass PAA will more isolate electronically $\mathrm{Si}$ and additive carbon.

Starting from the observation of polymer binder degradation during ball milling and in order to investigate the ball milling impact on cycling performance, a formulation without ball milling was considered (formulation 2 - SPEXfree). Therefore, Si, carbon, polymer binder, and $\mathrm{Tx}_{100}$ dispersant were magnetically stirmed in deionized water for 2 hours and then cast on a copper foil before drying, as previously described. The resulting electrodes were cycled in a coin cell versus $\mathrm{Li}^{+} / \mathrm{Li}^{\circ}$ and the active mass loading (in $\mathrm{mg} \mathrm{cm}^{-2}$ ) is 1.47 (Table $\mathrm{S} 1$, RSI†). This highly porous electrode (porosity is estimated around $70 \%$ - Table S1, ESI + , slightly higher than that with formulation 1) shows a 1st cycle CE of
$76 \%$, and a capacity of $3456 \mathrm{~mA} \mathrm{~h} \mathrm{~g}^{-1}$ and $170 \mathrm{~mA} \mathrm{~h} \mathrm{~g} \mathrm{~g}^{-1}$ for 1 st and 20 th charges, respectively. The observed polarization was 0.28 and $1.51 \mathrm{~V}$ at the 1 st cycle and 20 th cycle, respectively (Fig. 6). Here, fast capacity fading is observed and can be attributed to the absence of energetic silicon ball milling and good mixing with carbon and PAA binder. Several masons could be evoked for these low performances without silicon/carbon ball milling. First, energetic ball milling creates micro or nano-racks and defects, ie. reactive sites, and modifies the surface energy. All these phenomena enhance the electrochemical reactivity. ${ }^{63}$ Secondly, the absence of reduction of the oxidized Si surface, which can be induced by the additive carbon during energetic ball milling, could also be suggested to be the origin of these low performances. The low cyclability is correlated with an important polarization increase (from $0.28 \mathrm{~V}$ at the 1 st cycle to $1.51 \mathrm{~V}$ at the 20th). Moreover, as previously underlined, a silicon planetary ball milling induces actually a silicon nano-structuration thanks to grain boundary creation with, consequently, a better electrochemical cyclability for micrometer silicon. ${ }^{54}$ This nano- 

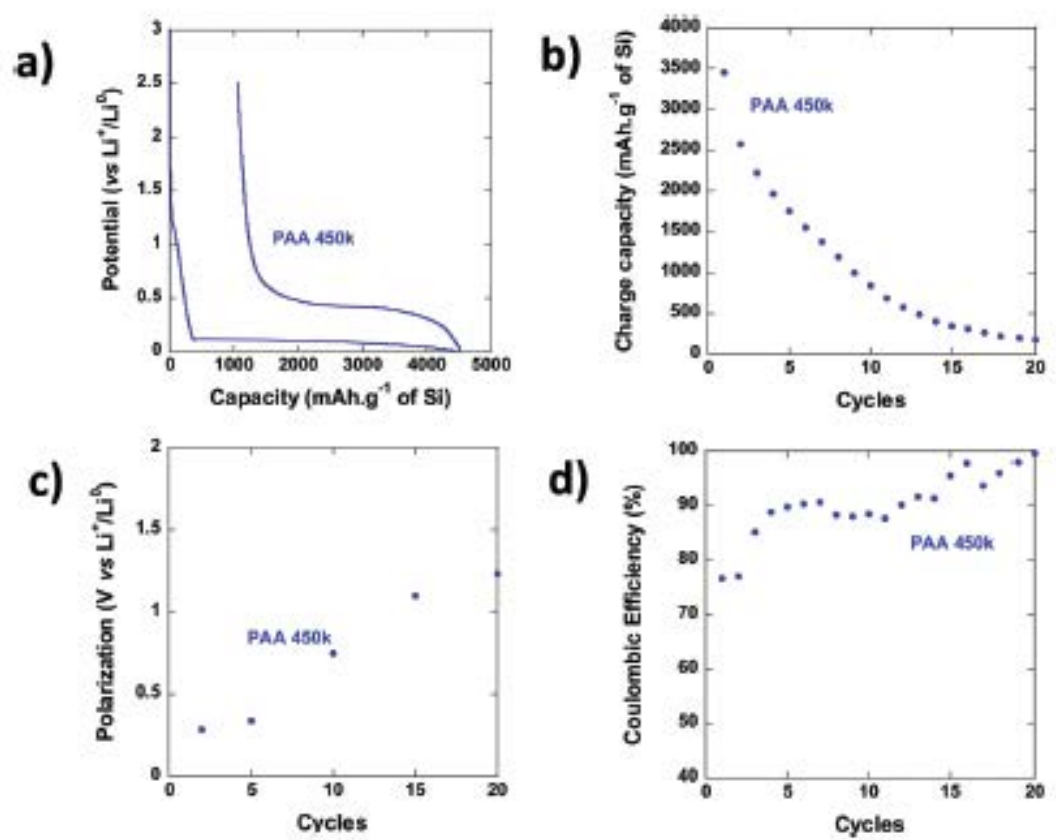

Fig. 6 Firs galvanostatic cycle profle (a), evolution of charge capacity with cycle curves (b), polarization evolu tion curves ic) and coulombic efficiency variation (d) of S/Cc65/binder electrodes (70/15/15 wZ) with formulation 2 using PAA $450 \mathrm{k}$ (blue line) (20 "C, C/10 (1 Li in 10 hours), LP30 + FEC (10 v26). versus $\mathrm{Li}^{+} / \mathrm{Li}$ )

structuration phenomenon, missing in our formulation 2 could finally also explain these weak performances.

Based on the two previous formulation results, we developed here an innovative formulation combining both energetic silicon milling and PAA stirring (formulation 3). This new process consists, first of SPEX dry ball milling of silicon and additive carbon, followed by an addition of PAA binder stirred with deionized water and dispersant to homogenize the slurry. The resulting 70/15/15 wt $\%$ slurry (Si/Cc65/PAA) was electrochemically characterized versus $\mathrm{Li}^{+} / \mathrm{Li}^{\circ}$, as previously described. The results are presented in Fig. 7 and summarized in Table 3. This new optimized formulation induces an electrochemical cyclability improvement for $15 \mathrm{k}$ and $450 \mathrm{k}$ PAAs. Indeed, a significant increase of the charge capacity retention from $23 \%$ to $62 \%$ is observed at the 20 th cycle for $15 \mathrm{k}$ PAA and from $62 \%$ to $84 \%$ for $450 \mathrm{k}$ PAA with formulation 3 compared with that of the previous "ball milling" formulation 1 . These cells exhibit charge capacities at the 20 th cycle of $2023 \mathrm{~mA} \mathrm{~h} \mathrm{~g}^{-1}$, $2957 \mathrm{~mA} \mathrm{~h} \mathrm{~g}^{-1}$ and $853 \mathrm{~mA} \mathrm{~h} \mathrm{~g}^{-1}$, respectively, for PAA $15 \mathrm{k}$, $450 \mathrm{k}$ and $3000 \mathrm{k}$. Besides, electrode porosities are estimated at about $70 \%$ for PAA $450 \mathrm{k}$ and $3000 \mathrm{k}$ electrodes ( $65 \%$ for PAA $15 \mathrm{k}$ ) against $60 \%$ in the usual SPEX formulation for PAA $450 \mathrm{k}$ and $3000 \mathrm{k}$ electrodes ( $65 \%$ for PAA $15 \mathrm{k}$ ) - (Table S1, ESI + ). The active mass loading values (in $\mathrm{mg} \mathrm{cm}^{-2}$ ) are, respectively, 1.12 for PAA $15 \mathrm{k}$ and $450 \mathrm{k}$ and 1.26 for PAA $3000 \mathrm{k}$ electrodes (Table S1, ESI $\dagger$ ). Moreover, the $15 \mathrm{k}$ and $450 \mathrm{k}$ PAA electrode polarization values remain almost constant along the first 20 cycles with a respective limited increase of 0.02 and $0.03 \mathrm{~V}$, whereas an increase from 0.34 to $0.52 \mathrm{~V}$ is observed for the $3000 \mathrm{k}$ PAA. The later clearly shows lower performances. Fig. 7 also shows that the coulombic efficiency (CE) is improved for the 450k PAAbased electrode in this formulation 3, compared to the $15 \mathrm{k}$ - and $3000 \mathrm{k}$-based electrodes. A value of about $95 \%$ is then reached at the 2 nd cycle, higher than the $15 \mathrm{k}(84.5 \%)$ and $3000 \mathrm{k}(73 \%)$-based electrodes values, at the same cycle.

SEM pictures of 450k PAA Si pristine electrodes of formulation 1 and 3 are presented in Fig. 8a and c. A significant morphological difference can be noticed here between the two formulations. The composite electrode formed of the $450 \mathrm{k}$ ball milling formulation presents a homogeneous surface with some noticeable cracks. In contrast, the optimized composite electrode presents a more complex morphology, without noticeable cracks and with a higher apparent porosity. These features would likely lead to better lithium/electron diffusion and consequently better electrochemical behavior. Formulation 1 and 3 washed post-mortem electrodes after 20 cycles (Fig. 8 b and d) exhibit a more compact surface with a global apparent porosity decrease. This observation is particularly true for the formulation 1 electrode which appears more impervious while the optimized electrode still presents some porosity. Such phenomena may be attributed to the SEIs which fill the pores of the electrode (formulation 1) and increase the resistivity to ions and electrons and decrease the performance while the optimized electrode (formulation 3) benefits from a better SEI structure allowing better performance. For comparison for both $450 \mathrm{k}$ - and $15 \mathrm{k}$-based electrodes, the polarization is quite constant during the first 20 cycles $(0.30 \mathrm{~V}$ for formulation 1 
a)
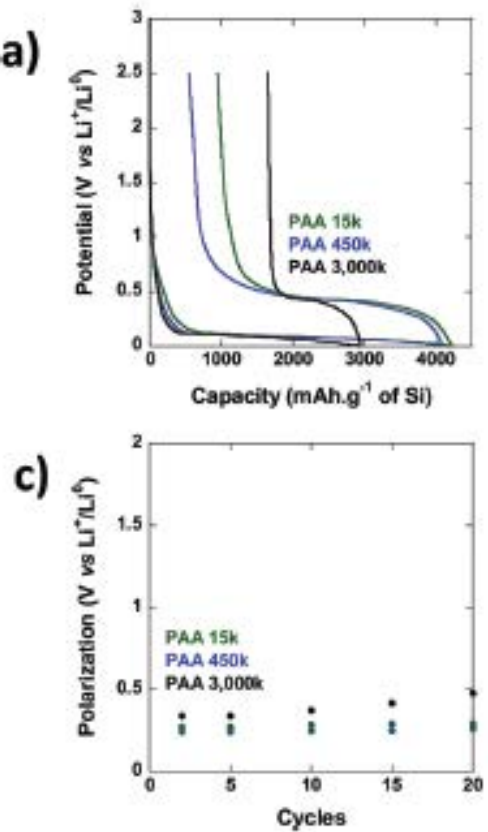

b)

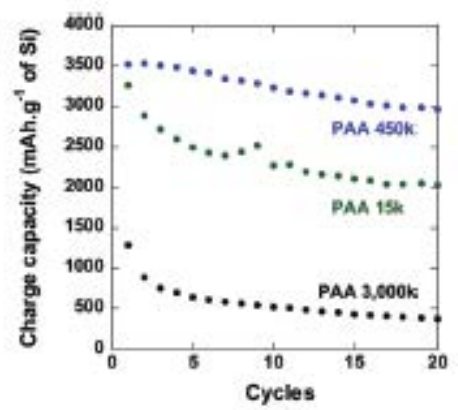

d)

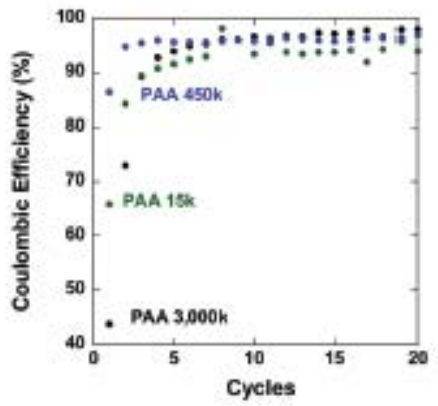

Fig. 7 First galvanostatic cycle profile (a), evolution of charge capacily with cycle curves (b) polarization evolution curves (c) and coulombic efficiency variation (d) of Si/Cc65/b inder electrodes (70/15/15 wta) with formulation 3 using PAA $15 k$ (green linel. PAA 450k (blue line) and PAA $3000 k$ (black line) $\left(200^{\circ} \mathrm{C}, \mathrm{C} / 10\right.$ (1 $\mathrm{L}$ in 10 hours) $L P 30+\mathrm{FEC}(10 \mathrm{v} \%)$ versus $\left.\mathrm{L}^{+} / \mathrm{Li}^{\circ}\right)$.

Table 3 Cell characteristics of $15 \%, 450 k$ and $3000 k$ PAA-besed electrodes using formulation 3

\begin{tabular}{llll}
\hline Formulation 3 & PMA 15k & PMA 450k & PA 3000k \\
\hline 1st charge $\left(\mathrm{mA} \mathrm{h} \mathrm{g}^{-1}\right)$ & 3263 & 3520 & 2941 \\
1st cycle CE $(\%)$ & 66 & 86 & 44 \\
20th charge $\left(\mathrm{m} \mathrm{h} \mathrm{g}^{-3}\right)$ & 202.3 & 2957 & 853 \\
20th charge/1st charge $(\%)$ & 62 & 84 & 29 \\
Polarization 1st cycle/20th cycle (V) & $0.27 / 0.29$ & $0.24 / 0.27$ & $0.34 / 0.52$
\end{tabular}

against $0.27 \mathrm{~V}$ for formulation 3). The retention of binder integrity can be therefore evolaed as responsible for this improvement. The absence of binder degradation involves a higher polymer average molar mass compared to that of its milled counterpart and induces, as a consequence, better interactions between electrode components, especially silicon. In this sense, this average molecular mass retention is favorable for 15 and $450 \mathrm{~kg} \mathrm{~mol}^{-1}$ PAA. On the contrary, in the case of the $3000 \mathrm{~kg} \mathrm{~mol}^{-1}$ PAAbased cell, the composite electrode suffers from the polymer critical molar mass and restricted electrochemical performances are observed, regardless of whether formulation 1 or 3 is used. It must be highlighted here that a relatively comparable PAA $\left(\bar{M}_{\mathrm{n}}=\right.$ $167 \mathrm{~kg} \mathrm{~mol}{ }^{-1}$ and $\bar{M}_{\mathrm{w}}=964 \mathrm{~kg} \mathrm{~mol}^{-1}$ ) gave also the best results in a very recent study of $\mathrm{Hu}$ et $a l^{37}$ on graphite rich silicon composite electrodes for Li-ion batteries. The higher initial specific capacity and higher average capacity over 100 cycles is indeed obtained for an electrode based on this polymer, compared to lower mass PAAbased electrodes. More widely, these authors suggest that a $\bar{M}_{n}$ range of 24 to $150 \mathrm{~kg} \mathrm{~mol}^{-1}$ permits optimized performance to be achieved. Here, this assertion can be confirmed in our case, with clear evidence that a PAA of $\bar{M}_{n}=$ $13 \mathrm{~kg} \mathrm{~mol} \mathrm{~g}^{-1}$ and $\bar{M}_{\mathrm{w}}=27 \mathrm{~kg} \mathrm{~mol}^{-1}$ gives lower perfomances. Interestingly, in complement to the study of $\mathrm{Hu}$ et al., we demonstrated here that a higher average molar mass PAA $\left(3000 \mathrm{~kg} \mathrm{~mol}^{-1}\right)$ also gives lower performance. This effect is probably linked to the limited solubility of this high molar mass PAA, limiting its dispersion in solution/electrolyte and, therefore, limiting its possibility to create covalent links to $\mathrm{SiOH}$ groups on the surface of Si. Furthermore, it must be highlighted here that in the study of Hu et al. the electrode intrinsic capacity is much lower than in our case due to the low $\%$ of $\mathrm{Si}$ in the composite. There, $15 \%$ of Si gives a maximum theoretical initial capacity of $854 \mathrm{~mA} \mathrm{~h} \mathrm{~g}^{-1}$ for the composite electrode. This value has to be compared to our maximum theoretical initial capacity of $3589 \mathrm{~mA} \mathrm{~h} \mathrm{~g}^{-1}$ for a composite electrode using only silicon as the active material. Here, in our best result (formulation 3 with PAA 450k) the initial charge capacity of $3520 \mathrm{~mA} \mathrm{~h} \mathrm{~g}^{-1}$ is decreased to $2957 \mathrm{~mA} \mathrm{~h} \mathrm{~g}^{-1}$ for the 20 th charge. Besides, another consequence of this low Si\% in the study of Hu et al. is that the electrode volume expansion during electrochemical cycling (breathing) is much lower than in our case, giving a much easier manageable electrode, especially with intrinsic better reversibility. Overall, a question can be asked here on the polymer binder impact in regard to the inherent active material capacity. In our opinion, this effect is easier to hightight if the electroactive material capacity is high, ie. with a Si rich electrode rather than with a carbon rich electrode. Nevertheless in the latter case discrepancies are higher. 

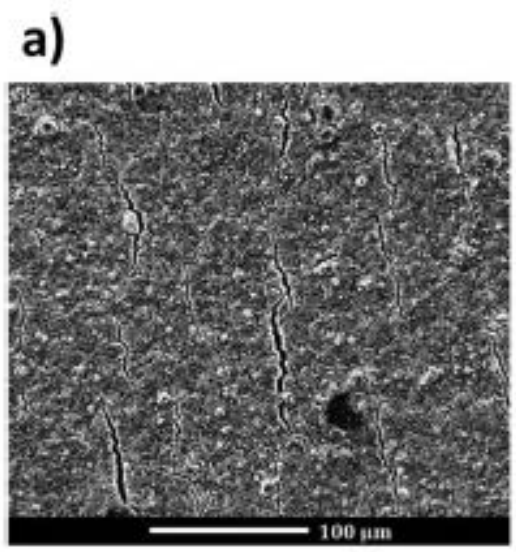

c)

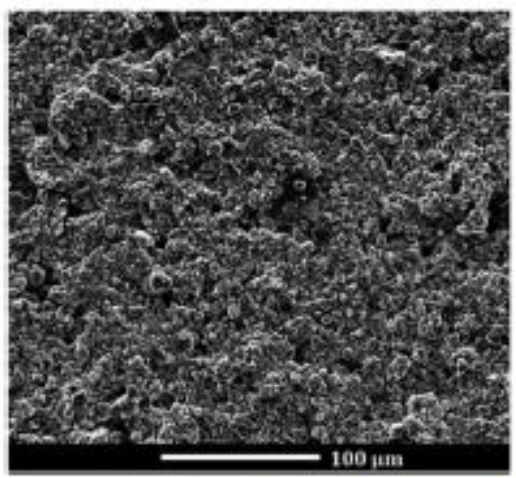

\section{b)}

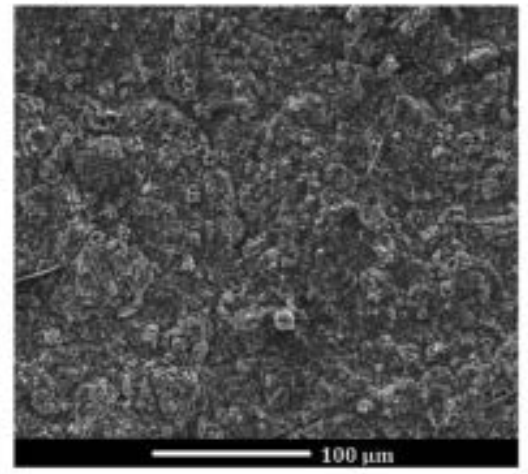

d)

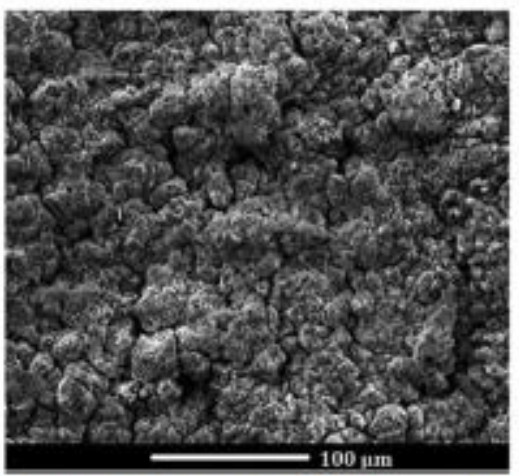

Fig. 8 SEM micrographs of the pristine 450K PAA-based formulaton 1 electrode (a) and the same after the 20 th char ge (b) and the pristine $450 \mathrm{k}$ PAAbased formulation 3 electrode $(\mathrm{c})$ and the same after the 20 th charge (d).

\section{Conclusions}

The detrimental effect of the energetic ball milling step on PAA binders used for Si-based electrode preparation and its strong impact on performance was demonstrated here for the first time. Several characterizations realized on pre- and post-ball milled PAA of three different commercial samples (PAA 15k, $450 \mathrm{k}, 3000 \mathrm{k}$ ) support this statement (SEC study, ${ }^{1} \mathrm{H}$ NMR, TGA analysis). SEC-MAIS analysis proved that the average molecular masses decrease for PAA $15 \mathrm{k}$ and $450 \mathrm{k}$, especially for PAA $450 \mathrm{k} ;{ }^{1} \mathrm{H}$ NMR demonstrates a resolution loss for all samples attributed to an increase of the different chemical environments and linked to chain degradation, especially for PAA $450 \mathrm{k}$. FIIR study does not show any difference between all pristine and ball milled polymers, meaning that there are no clearly noticeable chemical function changes. Finally, TGA study demonstrates a lower ther mal stability for all PAA samples after ball milling. More precisely, the small polymer sample (PAA $15 \mathrm{k}$ ) is not affected by energetic ball milling while higher molar mass PAAs (PAA $450 \mathrm{k}$ and $3000 \mathrm{k}$ ) suffer from this energetic milling step. Degradation seems to be maximum for PAA $450 \mathrm{k}$. Here, we also introduce an optimized formulation, with a wet ball milling of only carbon and $\mathrm{Si}$, this last step being necessary to get a homogeneous electrode able to give satisfactory performance. Increases of capacity retention at the 20 th cycle were observed with this optimized formulation, going from 65 to $84 \%$ and from 23 to $62 \%$, respectively, for $450 \mathrm{k}$ and $15 \mathrm{k}$ PAA-based composite anodes. PAA $3000 \mathrm{k}$ possesses limited solubility in solvents, which limits (i) its dispersion in the slurry and (ii) therefore its possibility to bond SiOH groups of Si particle surfaces and (iii) the performance in the battery. In addition, we confirm that polymer binder average molecular mass constitutes an important parameter regarding the Sibased electrode cyclability. There is no doubt that this conclusion may be extended to other pblock element-based electrodes. $^{37-40}$ Here, we suggest that the PAA optimal average molecular mass for a rich silicon-based anode $(70 \%)$ is close to $\widehat{M}_{\mathrm{a}}=191 \mathrm{~kg} \mathrm{~mol}{ }^{-1}$ and $\bar{M}_{\mathrm{w}}=495 \mathrm{~kg} \mathrm{~mol}^{-1}$ (PAA 450k), since lower performances have been obtained with lower or higher PAA average molar masses (PAA $15 \mathrm{k}$ and $3000 \mathrm{k}$ ). These results can be companed to the study of $\mathrm{Hu}$ et al. ${ }^{37}$ who estimated the optimum PAA with average masses of $\bar{M}_{\mathrm{n}}=167 \mathrm{~kg} \mathrm{~mol}^{-1}$ and $\bar{M}_{w}=964 \mathrm{~kg} \mathrm{~mol} \mathrm{l}^{-1}$. Nevertheless, it must be highlighted that this last study was realized with a graphite rich silicon composite electrode ( $15 \%$ of $\mathrm{Si}$ ). 


\section{Conflicts of interest}

The authors declare there are no conflicts of interest for this manuscript.

\section{Acknowledgements}

Financial support from the Buropean Union - FRDER (Fonds Buropéen de Développement Régional), from the CNRS, from the Région Picardie and from the RS2B (Ré seau sur le Stockage Electrochimique de l'Energie FR CNRS 3459) for the PENSA research project is gratefully acknowledged. The authors also deeply thank D. Cailleux and M. Courty for NMR and TGA experiments and "Platform of Electronic Microscopy" for help in SEM characterization.

\section{Notes and references}

1 J. M. Tarascon and M. Armand, Nature, 2001, 414, 359-367. 2 N.-S. Choi, Z. Chen, S. A. Freunberger, X. Ji, Y.-K. Sun, K. Amine, G. Yushin, L. F. Nazar, J. Cho and P. G. Bruce, Angew. Chem., Int. Ed, 2012, 51, 9994-10024.

3 B. Dunn, H. Kamath and J.-M. Tarascon, Science, 2011, 334, 928-935.

4 J. Swiatowska and P. Barboux, Lithium Process Chemistry, Elsevier, 1st edn, 2015, Pp. 137-149.

5 Y. Huang, X. Huang, J. Lian, D. Xu, L. Wang and X. Zhang, J. Mater. Chem, 2012, 22, 2844-2847.

6 X. Huang, R. Wang, D. Xu, Z. Wang, H. Wang, J. Xu, Z. Wu, Q. Liu, Y. Zhang and X. Zhang, Adv. Funct. Mater., 2013, 23, 4345-4353.

7 L. Aymard, Y. Oumellal and J.-P. Bonnet, Beilstein J. Nanotechnol., 2015, 6, 1821-1839.

8 U. Kasavajula, C. Wang and A. J. Appleby, J. Ptrver Sources, $2007,163,1003-1039$.

9 M. N. Obrovac and L. Christensen, Electrochem. Solid-State Lett, 2004, 7, A93-A96.

10 T. D. Hatchard and J. R. Dahn, J. Electrochem. Soc, 2004, 1.51, A838-A842.

11 J. Tirado, Mater. Sci. Eng., R, 2003, 40, 103-136.

12 C. K. Chan, H. Peng, G. Liu, K. Mellwrath, X. F. Zhang, R. A. Huggins and Y. Cui, Nat. Nanotechnol., 2008, 3, 31-35.

13 C. Chen, S. H. Lee, M. Cho, J. Kim and Y. Lee, ACS AppL. Mater. Interfaces, 2016, 8, 2658-2665.

14 K. Feng, M. Li, W. Liu, A. G. Kashkooli, X. Xiao, M. Cai and Z. Chen, Small, $2018,14,1702737$.

15 Z.-H. Wu, J.-Y. Yang, B. Yu, B.-M. Shi, C.-R. Zhao and Z.-L. Yu, Rare Met., 2016, 1-8.

16 K. W. Schroder, H. Celio, L. J. Webb and K. J. Stevenson, J. Phys Chem C, 2012, 116, 19737-19747.

17 J. Zhu, T. Wang, F. Fan, L. Mei and B. Lu, ACS Nano, 2016, 10, 8243-8251.

18 J. Wang, T. Xu, X. Huang, H. Li and T. Ma, RSCAdv., 2016, 6, 87778-87790.

19 T. D. Bogart, X. Lu, M. Gu, C. Wang and B. A. Korgel, RSC Adv. $2014,4,42022-42028$.
20 D. Ma, Z. Cao and A. Hu, Nano-Micro Lett., 2014, 6, 347-358.

21 X. Zuo, J. Zhu, P. Müller-Buschbaum and Y.J. Cheng, Nano Energy, 2017, 31, 113-143.

22 J. K. Lee, C. Oh, N. Kim, J.-Y. Hwang and Y.-K. Sun, J. Mater. Chem. A, 2016, 4, 5366-5384.

23 H. Li, X. Huang, L. Chen, Z. Wu and Y. Liang, Electrochem. Solid-State Lett, 1999, 2, 547-549.

24 H. Tian, F. Xin, X. Wang, W. He and W. Han, J. Materiomics, 2015, 1, 153-169.

25 X. H. Liu, L. Zhong, S. Huang, S. X. Mao, T. Zhu and J. Y. Huang, ACS Nano, 2012, 6, 1522-1531.

26 X. H. Liu and J. Y. Huang, Energy Environ. Sci, 2011, 4, 3844.

27 M.H. Park, M. G. Kim, J. Joo, K. Kim, J. Kim, S. Ahn, Y. Cui and J. Cho, Nano Lett., 2009, 9, 3844-3847.

28 C. K. Chan, H. Peng, G. Liu, K. Mcllwrath, X. F. Zhang, R. A. Huggins and Y. Cui, Nat. Nanotechnol, 2008, 3, 31-35.

29 T. Takamura, S. Ohara, M. Uehara, J. Suzuki and K. Sekine, J. Power Sources, 2004, 129, 96-100.

30 B. Lestricz, C. R. Chim. 2010, 13, 1341-1350.

31 N.S. Choi, S.-Y. Ha, Y. Lee, J. Y. Jang, M.-H. Jeong, W. C. Shin and M. Ue, J. Electrochem. Sci. Technol, 2015, 6, 35-49.

32 F. Beguin and R. Frackowiak, Carbons for Electrochemical Energy Storage and Conversion Systems, CRC Press, 1st edn, 2010 , p. 263.

33 M. Yoo, C. W. Frank, S. Mori and S. Yamaguchi, Chem. Mater., 2004, 16, 1945-1953.

34 M. Yoo, C. W. Frank and S. Mori, Chem. Mater., 2003, 15, 850-861.

35 M. Yoo, C. W. Frank, S. Mori and S. Yamaguchi, Polymer, $2003,44,4197-4204$.

36 B. Koo, H. Kim, Y. Cho, K. T. Lee, N.-S. Choi and J. Cho, Angew. Chem., Int. Ed., 2012, 51, 8762-8767.

37 B. Hu, I. A. Shkrob, S. Zhang, L. Zhang, J. Zhang, Y. Li, C. Liao, Z. Zhang, W. Lu and L. Zhang, J. Power Sources, $2018,378,671-676$.

38 H.-K. Park, B.-S. Kong and R.-S. Oh, Electrochem. Commun, $2011,13,1051-1053$.

39 J.S. Bridel, T. Azaīs, M. Morcrette, J.M. Tarascon and D. Larcher, Chem. Mater., 2010, 22, 1229-1241.

40 B.-R. Lee and B.-S. Oh, J. Phys. Chem. C, 2013, 117, 4404-4409. 41 Z. Karkar, D. Guyomard, L. Roué and B. Lestriez, Electrochim. Acta, 2017, 258, 453-466.

42 C. R. Hernandez, A. Etiemble, T. Douillard, D. Mazouzi, Z. Karkar, E. Maire, D. Guyomard, B. Lestriez and L. Roué, Adu Energy Mater., 2017, 8, 1701787.

43 J. Guo and C. Wang, Chem. Commun., 2010, 46, 1428-1430. 44 A. Tranchot, H. Idrissi, P. X. Thivel and L. Roué, J. Electrochem. Soc, 2016, 163, A1020-A1026.

45 M. Murase, N. Yabuuchi, Z.-J. Han, J.-Y. Son, Y.-T. Cui, H. Oji and S. Komaba, ChemSus Chem, 2012, 5, 2307-2311.

46 Z.-J. Han, K. Yamagiwa, N. Yabuuchi, J.-Y. Son, Y.-T. Cui, H. Oji, A. Kogure, T. Harada, S. Ishikawa, Y. Aoli and S. Komaba, Phys. Chem. Chem. Phys., 2015, 17, 3783-3795.

47 Z.-Y. Wu, L. Deng, J.-T. Li, Q.-S. Huang, Y.-Q. Lu, J. Liu, T. Zhang, L. Huang and S.-G. Sun, Electrochim. Acta, 2017, 245, 371-378. 
48 D. Liu, Y. Zhao, R. Tan, L.-L. Tian, Y. Liu, H. Chen and F. Pan, Nano Energy, 2017, 36, 206-212.

49 S. Lim, H. Chu, K. Lee, T. Yim, Y.J. Kim, J. Mun and T.-H. Kim, ACS Appl. Mater. Interfaces, 2015, 7, 23545-23553.

50 L. Lü, H. Lou, Y. Xiao, G. Zhang, C. Wang and Y. Deng, RSC Adv., 2018, 8, 4604-4609.

51 C. C. Nguyen, T. Yoon, D. M. Seo, P. Guduru and B. L. Lucht, ACS Appl. Mater. Interfaces, 2016, 8, 12211-12220.

52 J. Lopez, Z. Chen, C. Wang, S. C. Andrews, Y. Cui and Z. Bao, ACS Appl. Mater. Interfaces, 2016, 8, 2318-2324.

53 T. Ikonen, T. Nissinen, R. Pohjalainen, O. Sorsa, T. Kallio and V.-P. Lehto, Sci. Rep., 2017, 7, 7880.

54 M. Gauthier, D. Mazouzi, D. Reyter, B. Lestriez, P. Moreau, D. Guyomard and L. Roué, Energy Erviron. Sci, 2013, 6, 2145-2155.

55 A. P. Smith, J. S. Shay, R. J. Spontak, C. M. Balik, H. Ade, S. D. Smith and C. C. Koch, Polymer, 2000, 41, 6271-6283.
56 J. Dong, Y. Ozaki and K. Nakashima, J. Polym. Sci., Part B. Polym. Phys., 1997, 35, 507-515.

57 J. Spéváček, M. Suchopárek and S. Al-Alawi, Polymer, 1995, $36,4125-4130$.

58 C. Chang, D. D. Muccio and T. S. Pierre, Macromolecules, $1985,2154-2157$.

59 R. M. Woo and L. Chang, Encyclopedia of Polymer Science and Technology, American Cancer Society, 2011.

60 W. Kam, C.W. Liew, J. Y. Lim and S. Ramesh, Ionics, 2014, 20, 665-674.

61 I. C. MeNeill and S. M. T. Sadeghi, Polym. Degrad. Stab. $1990,29,233-246$.

62 H. L. Castricum, H. Yang, H. Bakleer and J. H. Van Deursen, Mater. Sci. Forum, 1997, 235-238, 211-216.

63 L. Aymard, C. Lenain, L. Courvoisier, F. Salver-Disma and J.M. Tarascon, J. Electrochem. Soc., 1999, 146, 2015-2023. 